\section{Bullying in the World of MMOG: Bullying Behavior, Coping Strat- egies and Psychological Analysis for College Students}

\author{
Shao-I Chiu* and Fu-Yuan Hong* \\ Graduate Institute of Professional Development in Education, DA-YEH \\ University, Taiwan
}

\begin{abstract}
This study examined the status of bullying behavior among college students in the world of MMOG (massive multiplayer online games), as well as risk factors that influence the bullying behavior of MMOG players and the impacts on individuals. A total of 290 university students in Taiwan completed an anonymous questionnaire to facilitate the assessment of the MMOG bullying behavior they had experienced during the previous month. The measurement tool covered MMOG bullying behavior, coping strategies, satisfaction with life and mental/physical health. The surveyed students indicated that people who were seen as chronic losers, sore losers and blamers were the most frequently-seen bullies. Typical desktop MMOG players, i.e. male junior/senior college students, scored higher for bullying behavior. Meanwhile, MMOG bullies showed a lower level of satisfaction with life. Finally, the bullying behavior of college students in the MMOG world was found to be a significant predicator of coping strategies in all dimensions.
\end{abstract}

Keywords: Coping strategies; Cyberbullying; Massive Multiplayer Online Games (MMOG); Satisfaction with life

\section{Introduction}

Bullying behavior is a prevalent phenomenon on campus that has attracted significant attention from educators. Cyberbullying is

*Corresponding authors: Shao-I Chiu, Graduate Institute of Professional Development in Education, DA-YEH University, Taiwan, E-mail: shaoi.chiu@msa. hinet.net

Fu-Yuan Hong, Graduate Institute of Professional Development in Education DA-YEH University, Taiwan, Tel: +886 982768339; E-mail: sames812@gmail. com

Citation: Chiu SI, Hong FY (2020) Bullying in the World of MMOG: Bullying Behavior, Coping Strategies and Psychological Analysis for College Students. J Addict Addictv Disord 7: 38.

Received: March 05, 2020; Accepted: March 12, 2020; Published: March 23, 2020

Copyright: @ 2020 Chiu SI, et al. This is an open-access article distributed under the terms of the Creative Commons Attribution License, which permits unrestricted use, distribution, and reproduction in any medium, provided the original author and source are credited. particularly commonplace these days that is a frequent occurrence among college students and has a negative impact on victims [1]. Cyberbullying is defined as the threat to others by an individual or a group through the repeated use of information and communication technology [2]. As cyberspace is perceived as a safe environment free from harmful behavior [3], teenagers are more likely to exhibit aggression in the cyber world than in the real world [4]. They are also likely to seek revenge in such an anonymous environment [5]. However, few studies have focused on the cyberbullying frequently seen in the online game world, particularly MMOG [6].

MMOG is highly social, anonymous and reinforcing in nature [710] and these characteristics facilitate cyberbullying [11]. The victims of bullying in the MMOG world can be described in the context of social relations $[12,13]$. Therefore, this paper assumed that the bullying in the MMOG world is a type of cyberbullying. The literature review on cyberbullying established a foundation for this paper in the examination of bullying in the MMOG world. Teenagers may not even be aware that they are dealing with bullying when they play MMOG games. Bullying behavior in the MMOG world has been neglected by researchers. Therefore, the paper analyzed the current status of bullying in MMOG games among college students, in order to decipher the risk factors for bullying and review the potential impact on individuals, in order to fill in the knowledge gap between bullying in the MMOG world and coping strategies.

\section{Cyberbullying styles}

Cyberbullying is exhibited on the Internet or via mobile devices in several ways, e.g. threats, harassment, harsh treatment, or social rejection [14-16]. This includes the distribution of unsolicited texts or pictures associated with sex and sexual harassment $[17,18]$. Bamford [19], stated that swearing (a sign of anger), insults, jokes (fluid) and nicknaming are frequently used techniques for cyberbullying. Lacey [20], suggested that the most prevalent cyberbullying behavior among students includes teasing, rumor spreading, insults and instant messaging threats. According to Ponsford [21], commonplace cyberbullying behavior among female students includes the revealing of others' secrets, gossiping in the virtual environment, attaching other personalities or gender identities, and labelling others as unreliable. In sum, cyberbullying is mostly verbal and sexual harassment. It is worth noting that identity concealment is also a cyberbullying pattern. Raskauskas and Stoltz [22], posited that because cyberbullies can easily hide their identities, it enhances the trauma felt by victims. The unknown identities of bullies in cyber space creates an imbalance between the bullies and the victims. As a result, the impact of cyberbullying is even more destructive than traditional campus bullying. Cyberbullies seek to attract attention by selectively broadcasting how they humiliate others [14]. Similarly, Shariff [23], found that information and communication technology allows people to create accounts by pretending to be others. This alone is sufficient to attract bullies. Finally, Çetin, Yaman and Peker [24], categorized cyberbullying according to identity concealment, oral cyberbullying and cyber forgery (e.g. insulting and defamatory language in emails). This paper further analyzed the patterns of bullying in the MMOG world. 


\section{Cyberbullying prevalence}

Literature suggests that cyberbullying is commonplace in high schools and universities [16,25], with a prevalence of $3.8 \%$ at the low end [26], to $34 \%$ at the high end [27]. The percentage of cyberbullying victims ranges from 5.3\% [26], to 49.5\% [22]. Wolak, Mitchell and Finkelhor [28], observed that $9 \%$ of teenagers have been exposed to cyberbullying. Among these victims, $57 \%$ are bullied by peers and $43 \%$ are bullied by strangers. A survey by Ybarra, West and Leaf [29], found that $64 \%$ of teenagers feel they are victims of cyberbullying. Beran and Li [30], suggested that most students have heard about cyberbullying and that $20 \%$ of them have been bullied multiple times. Only $3 \%$ of the surveyed students admitted to bullying others in cyberspace. In sum, cyberbullying is prevalent and the prevalence of bullying in the MMOG world identified in this paper requires further analysis.

\section{Cyberbullying risk factors}

Sex and age are considered important demographic factors in cyberbullying. The conclusions of the research on gender profile are inconsistent. For example, some studies have found that females are more likely to exhibit relationship bullying in cyberspace [31] and that females are more likely to become bullies and victims as well [32]. Other studies have argued that males are more aggressive in the cyber world [33] and are more likely to become bullies [25,26,33,34]. Some studies have indicated that the tendency toward cyberbullying is equal for both sexes $[15,35]$ and that victimization is not significantly different for males and females [16,36-38].

At the same time, age is also considered a key factor of cyberbullying. Research on junior high schools, senior high schools and universities has found that junior high school students exhibit more cyberbullying $[16,25]$. Other studies suggest that older students are more likely to become bullies and victims [32]. However, other studies have found that victims are not significantly different across age groups [36]. In a nutshell, the research findings on age as a factor in the context of cyberbullying are inclusive.

Finally, other risk factors of cyberbullying include frequent use of the Internet [28], long hours spent in front of a computer and sharing passwords with friends [32], sharing passwords with others and chatting online with strangers $[14,39]$, being a victim of campus violence [40] and having violent tendencies toward peers [32]. The victims of physical abuse in school are also more likely to become victims of cyber harassment [4], while victims of traditional bullying are also more likely to be victims of cyberbullying [22]. This paper examined the bullying behavior in MMOG games, particularly in reference to the types of games and methods involved, in order to analyze whether bullying behavior in the MMOG world is any different due to factors such as sex, age, game type and method.

\section{Cyberbullying influences}

Literature suggests a correlation between incidences of cyberbullying and symptoms of poor health, such as depression [36,41-45]; anxiety [42]; emotional disturbance [32,46,47]; extreme self-mutilation and suicide attempts [44]; suicidal tendency, high absenteeism and early dismissals [42]; truancy, probation and bringing weapons to school [48] and a reduction of life quality [49].

\section{Cyberbullying coping}

Lazarus and Folkman [50], believed that pressure and coping methods are both primary and secondary cognitive appraisal processes. In the primary cognitive appraisal, an individual assesses whether an incident is a threat. In the secondary cognitive appraisal, the individual selects coping strategies in order to appropriately leverage his/ her resources. If a pressure situation is deemed to be controllable, the individual will most likely seek to resolve the problems; if not, an emotional response will be adopted. Cyberbullying triggers a wide range of responses. Šleglova \& Cerna [47], conducted a qualitative analysis and classified the behavior factors of cyberbullying into technical coping, activity directed at the aggressor, avoidance of pressure situations, defense strategies, personal psychical help and social support. Parris, Varjas, Meyers and Cutts [51], divided coping strategies into responsive and preventive strategies. Responsive strategies are avoidance, acceptance, debate and seeking out social support. Preventive strategies (to prevent or mitigate the possibility of cyberbullying) include private talks, safety and awareness reinforcement. However, there sometimes are no preventive means. Responsive strategies include talking to teachers and friends, staying offline, not using the websites or software programs where bullies are active, doing nothing [52], pretending it is not there, ignoring its presence, bullying the bullies and deleting messages from bullies [53]. The most frequently used coping methods are telling someone and avoiding friends and peers [1]. In sum, not all the victims of cyberbullying resort to internalized coping. Some of them use externalized coping.

\section{Methodology}

\section{Participants}

The participants who completed the pretest were university students. The number of valid questionnaires recovered was 217 , of which $102(47.0 \%)$ were completed by men and $115(53.0 \%)$ were completed by women. Using purposive sampling, this study recruited students from three Taiwanese universities to serve as the study participants. A total of 300 questionnaires were distributed. The average response time for the scales was approximately $25 \mathrm{~min}$. Questionnaires with no or neutral responses were considered invalid and eliminated from the study sample. Following this elimination, the number of valid questionnaires recovered was 292 (a recovery rate of 97.33\%). When using the MLE method, data must satisfy the assumption of multivariate normality. Therefore, the sample size cannot be excessively small and the minimum suitable size is between 100 and 150 [54]. However, as the sample size increases, MLE may result in excessively sensitive models. Consequently, the sample size should be limited to under 300 or $400[55,56]$. Therefore, the sample size of this study (i.e., 387) satisfied these criteria. Of the samples, 83 were completed by freshmen $(28.4 \%), 63$ were completed by sophomores $(21.6 \%), 119$ were completed by juniors $(40.8 \%)$ and 27 were completed by seniors $(9.2 \%)$. In total, 97 of the respondents were men $(33.2 \%)$ and 195 were women $(66.8 \%)$.

\section{Measures}

This paper sought to understand the current status of bullying in the world of MMOG games and the potential coping strategies of the victims among university students. A literature review was conducted and interviews with the students were performed, in order to design measurements for bullying behavior during MMOG games and coping strategies. These two measurements went through a pretest. 
This paper analyzed validity using factor analysis and correlation analysis. The selection criteria were an eigenvalue of greater than 1 and the results of the screen tests. The promax method was used for oblique rotations, followed with the deletion of factors with loading smaller than 0.4 and questions with double loadings [57].

\section{Measurement of bullying on MMOG games}

A five-point Likert scale (with scores ranging from $0=$ not concerned to $4=$ more than 4 times concerned) was adopted. A higher score indicated more diverse cyberbullying concerns. If a surveyed college student reported a high total score, it would suggest that he/ she was perceiving and experiencing more bullying during MMOG games. Three questions were deleted after the pretest. The KMO value (Kaiser-Meyer-Olkin measure of sampling adequacy) stood at 0.942. Bartlett's tests yielded $\chi^{2}(276)=7917.543(\mathrm{p}<0.001)$ and a total of three factors were derived, i.e. dominant bullying (10 questions), verbal bullying (nine questions) and bullying by rejection (five questions). A total of 24 questions could explain $74.58 \%$ of the variances. The Cronbach's $\alpha$ coefficients were $0.95,0.96$ and 0.91 , respectively and the Cronbach's $\alpha$ coefficient for all questions was .98 , thus indicating good validity and reliability of the measurement.

\section{Measurement of coping strategies for bullying during MMOG games}

A three-point Likert scale (with scores ranging from 1=disagree to $3=$ agree) was adopted. If a surveyed college student exhibited a high total score, it would suggest that he/she was perceiving and adopting more pronounced copying strategies towards bullying in the world of MMOG games. Fifteen questions were deleted after the pretest. The KMO value (Kaiser-Meyer-Olkin measure of sampling adequacy) was 0.912 and Bartlett's tests showed $\chi 2(325)=5487.928(\mathrm{p}<0.001)$. A total of five factors were established, i.e. positive problem-solving (seven questions), verbal and emotional responses (five questions), tolerance and surrender (six questions), passive non-compliance (five questions) and responsive measures (three questions). A total of 26 questions could explain $70.05 \%$ of the variances. The Cronbach's $\alpha$ coefficients were $0.91,0.92,0.89,0.81$ and 0.84 , respectively and the Cronbach's $\alpha$ coefficient for all questions was 0.94 , thus indicating good validity and reliability of the measurement.

\section{Measurement of life satisfaction for college students}

The measurement of life satisfaction for college students was developed by $\mathrm{Li}$ and Hsieh [58], to evaluate the levels of satisfaction with life in general for university students. It contained a total of six questions that assess satisfaction with school work, leisure activities, interpersonal relations, family, intimacy and life in general. A sixpoint Likert scale (with scores ranging from $1=$ not all to $6=$ completely) was adopted. A high total score would indicate a high level of satisfaction with life in different aspects. The Cronbach's $\alpha$ coefficient for all questions was 0.91 , thus indicating good validity and reliability of the measurement.

\section{Measurement of mental/physical health}

The measurement of mental/physical health was designed using a translated version of the general health assessment by Chang [59] and a modified version of the measurement by Goldberger [60], to evaluate the mental and physical health of university students. A five-point Likert scale (with scores ranging from $0=$ not at all to $4=$ more than usual) was adopted. There was a total of 28 questions covering four factors: Physical symptoms (seven questions), anxiety and insomnia (seven questions), social dysfunction (seven questions) and severe depression (seven questions). The higher the total score or the score for individual factors, the better the subject's mental and physical health would be. The Cronbach's $\alpha$ coefficient was 0.97 , thus indicating good validity and reliability of the measurement.

\section{Data analysis}

This paper examined the relationship between the victimization of bullying during MMOG games and the adoption of coping strategies. A measurement was produced to profile college students who fall victim to bullying in the MMOG world and their coping strategies. First, this paper used descriptive statistics to analyze the current status of university students who are the victims of MMOG bullying and their coping strategies. Second, this paper conducted variance analysis on the bullying behavior imposed on victims as a result of factors such as sex, cohort (i.e. which year in university) and game type. Third, this paper delved into the potential psychological impact on students who fall victim to MMOG bullying (in contrast to those who do not). Variance analysis was conducted on whether the university students had been bullies themselves, how they were satisfied with life in general and their mental/physical health. Finally, this paper attempted to validate whether the measurement of coping strategies could be determined by the measurement of the bullying victims in the MMOG world by performing a stepwise regression and multiple regression analysis. The purpose was to gauge the predictability of the victimization of MMOG bullying on the coping strategies of college students. The predictive variables included dominating bullying, verbal bullying and bullying by rejection. The independent variables were positive problem-solving, verbal and emotional responses, tolerance and surrender, passive non-compliance and responsive measures, which have been shown in the measurement of coping strategies for bullying in the MMOG world.

\section{Results}

\section{Descriptive statistics}

Among the questionnaire respondents, a total of 116 subjects (or $40 \%$ of the total) had played MMOG games and experienced at least one bullying incidence within the past month. This number highlighted the seriousness of MMOG bullying. The most frequently-seen bullies experienced by over $20 \%$ of the surveyed college students at least once per month were chronic losers (25.0\%), sore losers (24.3\%) and blamers $(21.6 \%)$. The bullying behavior could be either dominating bullying or verbal bullying. The least frequently seen bullies, among those witnessed at least one per month, included rejections $(9.9 \%)$, removal from the team (11.0\%), stealing an account $(11.0 \%)$ and non-acceptance into the team (11.6\%). These least-seen bullying behaviors represent rejection in nature (Table 1).

\section{Analysis of bullying behavior imposed on MMOG college gamers in terms of gender, cohort, game type and device}

Table 2 presents the analysis on the variances of the bullying behavior imposed on MMOG college gamers in terms of gender, cohort, game type and device. The statistics included sample size, means, standard deviations, and T/F values. First, this paper found significant variances on the bullying behavior imposed on MMOG college gamers due to factors such as gender $(\mathrm{t}=5.88, \mathrm{p}<0.001)$, 
Citation: Chiu SI, Hong FY (2020) Bullying in the World of MMOG: Bullying Behavior, Coping Strategies and Psychological Analysis for College Students. J Addict Addictv Disord 7: 38.

- Page 4 of 10 •

cohort $(\mathrm{F}=6.16, \mathrm{p}<0.001)$, game type $(\mathrm{F}=16.52, \mathrm{p}<0.001)$, and device $(\mathrm{F}=2.85, \mathrm{p}<0.01)$. The variance analysis on ex-post game type suggested that male students scored higher than female students in the suffering of MMOG bullying. Junior and senior students (i.e. in the third and the fourth years) reported a higher score as victims of
MMOG bullying than freshman students. Desktop gamers were more likely to fall victim to MMOG bullying than gamers using other devices. Role-playing gamers were more likely to be victims of MMOG bullying compared to gamers in sports, racing and intellectual thinking.

\begin{tabular}{|c|c|c|c|c|c|c|c|}
\hline \multirow{2}{*}{\multicolumn{2}{|c|}{$\begin{array}{l}\text { Bullying Behaviour Experienced by MMOG } \\
\text { College Gamers }\end{array}$}} & \multicolumn{5}{|c|}{ Incidence Within One Month } & \multirow{3}{*}{$\begin{array}{c}\text { No. of Victims } \\
\text { No. of People (\%) }\end{array}$} \\
\hline & & \multirow{2}{*}{\begin{tabular}{|c|} 
0 Time \\
No. of People (\%) \\
\end{tabular}} & \multirow{2}{*}{\begin{tabular}{|c|}
1 Time \\
No. of People (\%) \\
\end{tabular}} & \multirow{2}{*}{\begin{tabular}{|c|}
2 Time \\
No. of People (\%)
\end{tabular}} & \multirow{2}{*}{\begin{tabular}{|c|}
3 Time \\
No. of People (\%) \\
\end{tabular}} & \multirow{2}{*}{\begin{tabular}{|c|}
4 Time \\
No. of People (\%)
\end{tabular}} & \\
\hline Type & Description & & & & & & \\
\hline \multirow{10}{*}{$\begin{array}{c}\text { Dominating } \\
\text { Bullying }\end{array}$} & Chronic losers & $219(75.0)$ & $19(6.5)$ & $17(5.8)$ & $11(3.8)$ & $26(8.9)$ & $73(25.0)$ \\
\hline & Attacking me each time & $247(84.6)$ & $15(5.1)$ & $8(2.7)$ & $3(1.0)$ & $19(6.5)$ & $45(15.4)$ \\
\hline & Malicious attacks & $244(83.6)$ & $15(5.1)$ & $11(3.8)$ & $5(1.7)$ & $17(5.8)$ & $48(16.4)$ \\
\hline & Cursing at each other & $241(82.5)$ & $14(4.8)$ & $16(5.5)$ & $2(0.7)$ & $19(6.5)$ & $51(17.5)$ \\
\hline & Teasing me for poor techniques & $237(81.2)$ & $22(7.5)$ & $11(3.8)$ & $5(1.7)$ & $17(5.8)$ & $55(18.8)$ \\
\hline & Calling me a lousy player & $246(84.2)$ & $16(5.5)$ & $12(4.1)$ & $3(1.0)$ & $15(5.1)$ & $46(15.8)$ \\
\hline & Calling me a low-level player & $249(85.3)$ & $20(6.9)$ & $7(2.4)$ & $3(1.0)$ & $13(4.5)$ & $43(14.7)$ \\
\hline & Suppressing me at games & $256(87.7)$ & $11(3.8)$ & $14(4.8)$ & $1(0.3)$ & $10(3.4)$ & $36(12.3)$ \\
\hline & Calling me good-for-nothing & $252(86.3)$ & $12(4.1)$ & $9(3.1)$ & $4(1.4)$ & $15(5.1)$ & $40(13.7)$ \\
\hline & Everybody picking on me & $255(87.3)$ & $19(6.5)$ & $4(1.4)$ & $1(0.3)$ & $13(4.5)$ & $37(12.7)$ \\
\hline \multirow{9}{*}{$\begin{array}{c}\text { Verbal } \\
\text { Bullying }\end{array}$} & Critical of my performance & $229(78.4)$ & $24(8.2)$ & $14(4.8)$ & $3(1.0)$ & $22(7.5)$ & $63(21.6)$ \\
\hline & Sore losers & $221(75.7)$ & $23(7.9)$ & $17(5.8)$ & $2(0.7)$ & $29(9.9)$ & $71(24.3)$ \\
\hline & Random and verbal attacks on others & $239(81.8)$ & $16(5.5)$ & $13(4.5)$ & $3(1.0)$ & $21(7.2)$ & $53(18.2)$ \\
\hline & Calling others lousy players & $238(81.5)$ & $15(5.2)$ & $16(5.5)$ & $7(2.4)$ & $16(5.5)$ & $54(18.5)$ \\
\hline & Personal attacks & $251(86.0)$ & $14(4.8)$ & $10(3.4)$ & $6(2.1)$ & $11(3.8)$ & $41(14.0)$ \\
\hline & Self-righteousness & $236(80.8)$ & $20(6.8)$ & $9(3.1)$ & $5(1.7)$ & $22(7.5)$ & $56(19.2)$ \\
\hline & Being unreasonable & $251(86.0)$ & $12(4.1)$ & $4(1.4)$ & $5(1.7)$ & $20(6.8)$ & $41(14.0)$ \\
\hline & Refusing to work as a team & $244(83.6)$ & $15(5.1)$ & $10(3.4)$ & $3(1.0)$ & $20(6.8)$ & $48(16.4)$ \\
\hline & Big talk but nothing done & $241(82.5)$ & $18(6.2)$ & $8(2.7)$ & $7(2.4)$ & $18(6.2)$ & $51(17.5)$ \\
\hline \multirow{5}{*}{$\begin{array}{c}\text { Bullying by } \\
\text { Rejection }\end{array}$} & Robbing me of my treasury & $240(82.2)$ & $13(4.5)$ & $14(4.8)$ & $5(1.7)$ & $20(6.8)$ & $52(17.8)$ \\
\hline & Being rejected & $263(90.1)$ & $5(1.7)$ & $9(3.1)$ & $1(0.3)$ & $14(4.8)$ & $29(9.9)$ \\
\hline & Not allowing me to join & $258(88.4)$ & $13(4.5)$ & $6(2.1)$ & $2(0.7)$ & $13(4.5)$ & $32(11.6)$ \\
\hline & Kicking me out & $260(89.0)$ & $12(4.1)$ & $8(2.7)$ & $2(0.7)$ & $10(3.4)$ & $32(11.0)$ \\
\hline & Stealing my account & $260(89.0)$ & $14(4.8)$ & $9(3.1)$ & $3(1.0)$ & $6(2.1)$ & $32(11.0)$ \\
\hline
\end{tabular}

Table 1: Descriptive Statistics of the Bullying Behavior Experienced by MMOG College Gamers.

\begin{tabular}{|c|c|c|c|c|c|c|}
\hline & Gender, Cohort, Game Types, Devices & Sample Size & Means & Standard Deviation & T/f Value & Ex-post Comparison \\
\hline \multirow{6}{*}{$\begin{array}{l}\text { Victim of MMOG } \\
\text { bullying }\end{array}$} & 1 Male & 95 & 20.59 & 26.95 & \multirow{2}{*}{$5.88 * * *$} & \multirow{2}{*}{$1>2$} \\
\hline & 2 Female & 195 & 3.76 & 10.36 & & \\
\hline & 1 Freshman & 83 & 3.06 & 8.20 & \multirow{4}{*}{$6.16^{* * *}$} & \multirow{4}{*}{$3,4>1$} \\
\hline & 2 Sophomore & 63 & 7.39 & 17.70 & & \\
\hline & 3 Junior & 119 & 13.05 & 22.63 & & \\
\hline & 4 Senior & 25 & 16.70 & 25.26 & & \\
\hline \multirow{4}{*}{$\begin{array}{l}\text { Victim of MMOG } \\
\text { bullying }\end{array}$} & 1 Smartphone & 190 & 4.68 & 13.64 & \multirow{4}{*}{$16.52 * * *$} & \multirow{4}{*}{$\begin{array}{l}2>1,3,4 \\
1,2,3>4\end{array}$} \\
\hline & 2 Desktop & 65 & 22.60 & 27.79 & & \\
\hline & 3 Notebook & 32 & 10.34 & 14.75 & & \\
\hline & 4 Tablet & 3 & 0.33 & 0.58 & & \\
\hline \multirow{8}{*}{$\begin{array}{l}\text { Victim of MMOG } \\
\text { bullying }\end{array}$} & 1 Role playing & 55 & 21.95 & 28.77 & \multirow{8}{*}{$2.85^{* *}$} & \multirow{8}{*}{$1>4,5,8$} \\
\hline & 2 Action & 39 & 12.21 & 23.40 & & \\
\hline & 3 Shooting & 17 & 12.47 & 15.35 & & \\
\hline & 4 Sports & 7 & 1.57 & 3.74 & & \\
\hline & 5 Racing & 12 & 4.83 & 8.19 & & \\
\hline & 6 Adventure & 16 & 9.66 & 18.13 & & \\
\hline & 7 Strategy and simulations & 33 & 9.61 & 15.91 & & \\
\hline & 8 Intellectual games & 63 & 2.71 & 10.11 & & \\
\hline
\end{tabular}

Table 2: Analysis of the bullying behavior imposed on MMOG College gamers in terms of gender, cohort, device and game type. Note: $* * \mathrm{p}<0.01 ; * * * \mathrm{p}<0.001$. 


\section{Variance analysis of the psychological impact on college students who fall victim to MMOG bullying}

Table 3 presents the variance analysis of the effects on college students who fall victim to MMOG bullying (vs. those who do not) in terms of their satisfaction with life and mental/physical health. The statistics included sample size, means, standard deviation and $T$ values of life satisfaction and mental/physical health. The study found no significant variances in terms of mental/physical health whether they suffered from MMOG bullying or not. It was worth noting that the life satisfaction of the students who had experienced MMOG bullying at least once per month was lower than those who had not $(t=2.85$, $\mathrm{p}<0.01)$.

\section{Related analysis}

This paper examined the correlation between the measurement of the victims of MMOG bullying and the selection of coping strategies. The results are shown in table 4 . There was a significant correlation between bullying by rejection and positive problem-solving, between bullying by rejection and verbal and emotional responses, between verbal bullying and verbal and emotional responses and between bullying by rejection and tolerance and surrender. Passive non-compliance was significantly and positively correlated with dominating bullying, verbal bullying and bullying by rejection. However, responsive measures were not significantly correlated with dominating bullying, verbal bullying or bullying by rejection. It was also worth noting that there was a significant and positive correlation between the number of hours per day spent on MMOGs and the victimization of MMOG bullying $(\mathrm{r}=0.35, \mathrm{p}<0.001)$.

\section{Analysis of variables}

This paper conducted stepwise multiple regression and analysis to examine the different coping strategies of the victims for different bullying patterns in the MMOG world. The purpose was to gauge the explanatory power of positive problem-solving, verbal and emotional responses, tolerance and surrender, passive non-compliance and responsive measures. This paper referred to the MMOG bullying patterns experienced by college students (such as dominating bullying, verbal bullying and bullying by rejection) as the predicative variable and coping strategies as the independent variable, with the purpose of analyzing the predictive power. All the tolerance values or Variance Inflation Factors (VIFs) of independent variables were tested in order to ensure the absence of multicollinearity. Among the four regression analyses, the highest VIF value was 1.00 and the lowest tolerance value was 1.00 . These numbers suggested that the analysis did not have the problem of multicollinearity.

First, positive problem-solving was referred to as an independent variable. MMOG bullying by rejection could effectively explain $3.4 \%$ of the variances associated with positive problem-solving $[\mathrm{F}$ $(1,291)=4.07, p=0.046]$. In the face of bullying by rejection $[t=2.02$, $\mathrm{p}=0.046]$, the subjects were more likely to cope using positive problem-solving. Verbal bullying could effectively explain $9.0 \%$ of the variances associated with verbal and emotional responses as an independent variable $[\mathrm{F}(1,291)=11.261, \mathrm{p}=0.001]$. When confronted with verbal bullying $[t=3.36, p=0.001]$, the subjects were more likely to cope using verbal and emotional responses. Dominating bullying could effectively explain $5.2 \%$ of the variances in relation to tolerance and surrender as an independent variable $[\mathrm{F}(1,291)=6.217$, $\mathrm{p}=0.014]$. When faced with dominating bullying $[\mathrm{t}=2.49, \mathrm{p}=0.014]$, the subjects were more likely to tolerate and surrender. Finally, bullying by rejection could effectively explain $9.7 \%$ of the variances associated with passive non-compliance as an independent variable $[\mathrm{F}(1,291)=12.259, \mathrm{p}=0.001]$. When dealing with bullying by rejection $[t=3.50, p=0.001]$, the subjects were more likely to respond with passive non-compliance. None of the MMOG bullying measurements could significantly predict responsive measures as an independent variable. The stepwise multiple regression results are summarized in table 5 .

\begin{tabular}{|c|c|c|c|c|c|}
\hline & Victim of MMOG Bullying & Sample Size & Means & Standard Deviation & T Value \\
\hline \multirow{2}{*}{ Life satisfaction } & No & 174 & 26.17 & 6.49 & \multirow{2}{*}{$2.85^{* *}$} \\
\cline { 2 - 5 } & Yes & 116 & 23.97 & 6.43 & \multirow{2}{*}{0.60} \\
\hline \multirow{2}{*}{ Mental/physical health } & No & 174 & 22.08 & 6.97 & 7.58 \\
\cline { 2 - 5 } & Yes & 116 & 21.56 & & \\
\hline
\end{tabular}

Table 3: Variance analysis on the life satisfaction and mental/physical health of college students who fall victim to MMOG bullying. Note: $* * \mathrm{p}<0.01$

\begin{tabular}{|c|c|c|c|c|c|c|c|c|}
\hline & 1 & 2 & 3 & 4 & 5 & 6 & 7 & 8 \\
\hline 1. Dominating bullying & 1 & & & & & & & \\
\hline 2. Verbal bullying & $0.780^{* * *}$ & 1 & & & & & & \\
\hline 3. Bullying by rejection & $0.652^{* * *}$ & $0.694^{* *}$ & 1 & & & & & \\
\hline 4. Positive problem-solving & 0.160 & 0.089 & $0.186^{*}$ & 1 & & & & \\
\hline 5. Verbal and emotional responses & $0.249 * *$ & $0.300^{* * *}$ & 0.085 & $0.376^{* * *}$ & 1 & & & \\
\hline 6. Tolerance and surrender & $0.227^{*}$ & 0.150 & 0.137 & $0.188^{*}$ & 0.101 & 1 & & \\
\hline 7. Passive non-compliance & $0.246^{* *}$ & $0.258^{* *}$ & $0.312 * * *$ & $0.512 * * *$ & $0.414 * * *$ & $0.403^{* * *}$ & 1 & \\
\hline 8. Responsive measures & 0.169 & 0.154 & 0.052 & $0.464 * * *$ & $0.332 * * *$ & 0.080 & $0.338^{* * *}$ & 1 \\
\hline
\end{tabular}

Note: $* \mathrm{p}<0.05 ; * * \mathrm{p}<0.01 ; * * * \mathrm{p}<0.001$

Table 4: Correlation analysis. 


\begin{tabular}{|c|c|c|c|c|c|c|c|c|}
\hline \multirow[b]{3}{*}{ Predictors } & \multicolumn{8}{|c|}{ Measurement of Coping Strategies (Independent Variable) } \\
\hline & \multicolumn{2}{|c|}{ Positive Problem-Solving } & \multicolumn{2}{|c|}{ Verbal and Emotional Responses } & \multicolumn{2}{|c|}{ Tolerance and Surrender } & \multicolumn{2}{|c|}{ Passive Non-Compliance } \\
\hline & B & $t$ & $\beta$ & $t$ & $\beta$ & $\mathrm{T}$ & B & $t$ \\
\hline Dominating bullying & & & & & 0.23 & $2.49 *$ & & \\
\hline Verbal bullying & & & 0.30 & $3.36^{* * *}$ & & & & \\
\hline Bullying by rejection & 0.19 & $2.02 *$ & & & & & 0.31 & $3.50 * * *$ \\
\hline
\end{tabular}

Table 5: Analysis on the predictors of coping strategies for college students who fall victim to MMOG bullying.

Note: $* \mathrm{p}<0.05 ; * * * \mathrm{p}<0.001$

\section{Discussion}

In contrast with past studies on cyberbullying of students, this paper focused on MMOG bullying as part of cyber interactions and conducted a preliminary exploration on the potential negative interactions between peers in an MMOG environment. In addition, this paper assumed that MMOG bullying may be detrimental to life satisfaction, mental/physical health and the use of various coping strategies. This study asked the surveyed college students to identify the MMOG bullying and potential risk factors they had perceived during the past month. This paper then analyzed the psychological impact on college students affected by MMOG bullying. It also explored the coping strategies most likely to be used by students in the face of MMOG bullying.

This paper found that $40 \%$ of the college students surveyed had fallen victim to MMOG bullying over the past month, which seemed slightly higher than for other cyberbullying behavior $[15,61,62]$. This highlighted the seriousness of MMOG bullying and the necessity to take action. Whilst MMOG bullying is a type of cyberbullying, this paper believed that MMOG bullying is more related to the behavior of the victims. Chronic losers, sore losers and blamers are typical bullies. These frequently-seen behaviors are largely consistent with the repetitive patterns of cyberbullying. They are also traits of social and psychological attackers $[2,20,23]$. In fact, compared to traditional bullying and cyberbullying in general, MMOG bullying may be even more targeted, purposeful and collective. As MMOGs are mission-oriented, the underperformance of certain members may drag the team down. Therefore, group bullying is even more likely. This study did not notice any distribution of texts, graphs or harassment asking for sex in the MMOG world. This result was different from typical cyberbullying. Rejection, being kicked out of the team, stealing accounts and non-acceptance as a team member were less-frequently seen among university students. Whilst pretending to be another user (such as stealing accounts) does exist as a bullying pattern in the MMOG world [23], the incidence is not frequent and it does not seem to be attractive to bullies. Follow-up studies may take a step further by analyzing the main reasons why people fall victim to bullying in the MMOG world. The findings could serve as a reference to the prevention of MMOG bullying.

This paper found that gender, cohort, game type and device could be the key risk factors for the victimization of MMOG bullying. This is particularly true with male students in their junior/senior years of college. However, the research findings in this paper ran contrary to past findings that females are more likely to be cyberbullies and victims [32]. This paper found no significant variances between male and female victims of cyberbullying $[16,32,36,38]$, possibly because males are more interested in online games than females [63] and are more willing to spend time playing online games [28]. As a result, they are more likely to be exposed to bullying. The findings for junior/ senior students were consistent with Mishna et al. [32]. This could be because the power dynamics in MMOG games are different from those in traditional bullying [64]. Whilst aggressive behavior is reduced in school, it may appear in other forms outside campus, such as cyberbullying and MMOG bullying [65]. Therefore, junior/senior students are more likely to fall vulnerable to MMOG bullying.

Finally, this paper indicated that college students who use desktop computers for role-playing games are more likely to fall victim to MMOG bullying. As desktops boast superior performance and equipment support compared to other devices, players who use desktops enhance the sustainability of the games and invite more people to join. In the meantime, online games with many multiple players aim to exchange ideas, feelings and thoughts between players. They usually work together or interact for the same goal. This is how friendships are established $[66,67]$ and is why players are keen to play such games. However, the high level of interactions and purposefulness can cause players with poor performance to be subject to bullying from others. This paper found a significant and positive correlation between the average hours per day spent playing online and bullying behavior in the MMOG world, finding that longer hours spent on online games would result in increased exposure to MMOG bullying. These results were consistent with expectations.

The research findings in this paper suggested that life satisfaction is lower for college students who have experienced MMOG bullying at least once per month. This result supported the research hypothesis and existing literature [49]. The subjective perceptions about life reflect whether university students feel their life needs have been satisfied. This is perhaps because college students hope to meet their needs for leisure and interpersonal relationships from online games. Such needs cannot be fulfilled effectively if they fall victim to cyberbullying. This will be reflected with life satisfaction. It was worth noting that this study found no significant correlation between MMOG bullying and mental/physical health. This finding was not consistent with past studies on cyberbullying. The result was possibly because of the emphasis on mission and purpose in the MMOG world. If players can play their roles effectively and help the team to win, they will be less likely to experience bullying from others. It is normal for the strong to bully the weak in the MMOG world. However, power dynamics are determined by the level of the roles played, not by physical size and strength and the impact on the mental/physical health of players is thus reduced.

Finally, this paper found that the different types of MMOG bullying that college students fall victim to could serve as a good predicator to coping strategies. In the face of bullying by rejection, 
Citation: Chiu SI, Hong FY (2020) Bullying in the World of MMOG: Bullying Behavior, Coping Strategies and Psychological Analysis for College Students. J Addict Addictv Disord 7: 38

university students are more likely to resort to positive problem-solving (a positive response) or passive non-compliance (a negative response). Whilst bullying by rejection (such as stealing treasure, stealing accounts, being rejected by others, not being accepted into the team and being kicked out of the team) are annoying, these bullying behaviors violate the MMOG game rules. In this circumstance, college students tend to opt out of the game, not team up, politely tell the other party that it is a bad idea or seek to reason with the other party. These can be either positive or passive coping strategies. If confronted with dominating bullying, it may be a consequence of the victim's own inferior technique or level as a game player. Perhaps the affected university students believe that their improvement in technique or level as players should mitigate the bullying they have been experiencing. Therefore, tolerance and surrender are likely coping strategies. Verbal bullying is likely to trigger verbal and emotional responses, as verbal bullying is not concerned with the prowess or technique of the game players. In fact, there are more verbal abuse and personal attacks in cyberbullying. Therefore, university students tend to resort to externalized coping such as verbal and emotional responses. In other words, verbal bullying in the gaming world is repulsive to victims and the response is through objects, matters and people in the environment. Examples include blaming others, calling others names and giving verbal warnings. Finally, the oral expression of unhappiness and annoyance causes both parties to feel upset. This may result in conflicts.

Some limitations may have affected the research findings of this paper. First, it is important to examine the nature of bullying in the MMOG world. This paper asked the surveyed students to recall whether they had experienced bullying when they played MMOGs during the past month. There may have been validity problems due to unknowns in the virtual gaming scenario. This brought up a number of questions. Is the bullying behavior specific to the MMOG world? What are the degrees of severity for such bullying behavior? What is the real response from students to MMOG bullying? Will individuals use the coping strategies discussed by this paper, or are there specific coping mechanisms developed by students? These generalized problems require analysis in the cyber world of online games using observations and experiments, which could shed light on the prevalence of bullying in MMOGs and its impact on university students.

Another research limitation was about correlations. As this study was not based on longitudinal research, it was not possible to conclude that bullying in the MMOG world reduces life satisfaction or cause other problems for university students. Follow-up studies may consider examining the adverse effects on younger or older age groups and conduct longitudinal research. Finally, this paper analyzed students in three colleges in northern Taiwan; therefore, the generalizations made may be limited.

The research findings also provided possible directions for future studies. Whilst bullying in the MMOG world is part of cyberbullying, there have been no relevant studies on the bullying of gamers. This paper explored the relationship between MMOG bullying behavior and coping strategies, but it did not delve into different actors, e.g. bullies, victims and onlookers, the personality characteristics that may be affected, the scenarios of the virtual games, or the impact on the mental/physical health of the persons involved. These may be directions for future studies. It is worth noting that bullying behavior in the gaming world may be person-to-person or group-to-person. However, this study could not effectively tell whether the usual suspects were acquaintances or strangers. What is the connection between bullying on the bully and bullying in general? These are all issues that can be analyzed in detail.

\section{Highlights}

- The chronic losers, sore losers and blamers were the most frequently bullies in MMOG.

- The male and scored higher MMOG players emerge bullying behavior.

- MMOG bullies showed a lower level of satisfaction with life.

- The bullying behavior in the MMOG world was significant predicator of coping strategies.

\section{References}

1. Schenka AM, Fremouwa WJ (2012) Prevalence, psychological impact, and coping of cyberbully victims among college students. Journal of School Violence 11: 21-37.

2. Belsey B (2007) Cyberbullying: A real and growing threat. ATA Magazine 88: $14-21$

3. Kowalski RM, Limber SP (2007) Electronic bullying among middle school students. J Adolesc Health 41: 522-530.

4. Ybarra ML, Mitchell KJ (2004) Online aggressor/targets, aggressors and targets: A comparison of associated youth characteristics. J Child Psychol Psychiatry 45: 1308-1316.

5. King J, Walpole C, Lamon K (2007) Surf and turf wars online-growing implications of internet gang violence. J Adolesc Health 41: 66-68.

6. Kelly RV (2014) Massively multiplayer online role-playing games: The people, the addiction and the playing experience. Mcfarland, USA.

7. Bessière K, Seay AF, Kiesler S (2007) The ideal elf: Identity exploration in World of Warcraft. Cyberpsychol Behav 10: 530-535.

8. Cole H, Griffiths MD (2007) Social interactions in massively multiplayer online role-playing gamers. Cyberpsychol Behav 10: 575-583.

9. Kuss DJ, Griffiths MD (2012) Online gaming addiction: A systematic review of empirical research. International Journal of Mental Health and Addiction 10: 278-296

10. Sánchez-Carbonell X, Beranuy M, Castellana M, Chamarro A, Oberst U (2008) Internet and cell phone addiction: Passing fad or disorder? Adicciones 20: 149-160.

11. Kowalski RM, Limber P, Agatston PW (2008) Cyberbullying: Bullying in the digital age. John Wiley \& Sons, New Jersey, USA

12. Hoff DL, Mitchell SN (2008) Cyberbullying: Causes, effects and remedies. Journal of Educational Administration 47: 652-665.

13. Mishna F, Saini M, Solomon S (2009) Ongoing and online: Children and youth's perceptions of cyber bullying. Children and Youth Services Review 31: 1222-1228.

14. Hinduja S, Patchin JW (2009) Bullying beyond the schoolyard: Preventing and responding to cyberbullying. Carwin Press, California, USA.

15. Patchin JW, Hinduja S (2006) Bullies move beyond the school yard: A preliminary look at cyber bullying. Youth Violence and Juvenile Justice 4: $148-169$.

16. Williams KR, Guerra NG (2007) Prevalence and predictors of Internet bullying. J Adolesc Health 41: 14-21. 
Citation: Chiu SI, Hong FY (2020) Bullying in the World of MMOG: Bullying Behavior, Coping Strategies and Psychological Analysis for College Students. J Addict Addictv Disord 7: 38.

17. Hinduja S, Patchin JW (2008) Cyberbullying: An exploratory analysis of factors related to offending and victimization. Deviant Behaviour 29: 129156.

18. Shariff S, Johnny L (2007) Cyber-libel and cyber bullying: Can schools protect student reputations and free expression in virtual environments? McGill Journal of Education 16: 307-342.

19. Bamford A (2004) Cyber-bullying. Ahisa pastoral care national conference. Melbourne, Australia.

20. Lacey B (2007) Social aggression: A study of internet harassment. Unpublished Doctoral Dissertation, Long Island University.

21. Ponsford J (2007) The future of adolescent female cyber-bullying: Electronic media's effect on aggressive female communication. Unpublished honors thesis, Texas State Universty, Texas, USA.

22. Raskauskas J, Stoltz AD (2007) Involvement in traditional and electronic bullying among adolescents. Developmental Psychology 43: 564-575.

23. Shariff S (2008) Cyber-bullying. Issues and solutions for the school, the classroom and the home. Taylor \& Francis, New York, USA

24. Çetin B, Yaman E, Peker A (2011) Cyber victim and bullying scale: A study of validity and reliability. Computers \& Education 57: 2261-2271

25. Wang J, Iannotti RJ, Luk JW (2012) Patterns of adolescent bullying behaviors: Physical, verbal, exclusion, rumor and cyber. J Sch Psychol 50: 521-534.

26. Wang J, Iannotti RJ, Nansel TR (2009) School bullying among adolescents in the United States: Physical, verbal, relational and cyber. J Adolesc Health 45: 368-375

27. Mishna F, Cook C, Gadalla T, Daciuk J, Solomon S (2010) Cyber bullying behaviours among middle and high school students. Am J Orthopsychiatry 80: $362-374$.

28. Wolak J, Mitchell KJ, Finkelhor D (2007) Does online harassment constitute bullying? An exploration of online harassment by known peers and online-only contacts. J Adolesc Health 41: 51-58.

29. Ybarra M, West MD, Leaf P (2007) Examining the overlap in Interne harassment and school bullying: implications for school intervention. $J$ Adolesc Health 41: 42-50.

30. Beran T, Li Q (2005) Cyber-harassment: A study of a new method for an old behaviour. Journal of Educational Computing Research 32: 265-277.

31. Keith S, Martin ME (2005) Cyber bullying: Creating culture of respect in a cyber world. Reclaiming Children and Youth 13: 224-228.

32. Mishna F, Khoury-Kassabri M, Gadalla T, Daciuk J (2012) Risk factors for involvement in cyber bullying: Victims, bullies and bully-victims. Children and Youth Services Review 34: 63-70.

33. Li Q (2006) Cyberbullying in schools: A research of gender differences School Psychology International 27: 157-170.

34. Aricak T, Siyahhan S, Uzunhasanoglu A, Saribeyoglu S, Ciplak S, et al. (2008) Cyberbullying among Turkish adolescents. Cyberpsychol Behav 11: $253-261$

35. Syts Y (2004) Beyond the schoolyard: Examining electronic bullying among Canadian youth. Unpublished master's thesis, Carleton University, Ottawa, Ontario.

36. Baker ÖE, Tanrikulu İ (2010) Psychological consequences of cyber bullying experiences among Turkish secondary school children. Procedia Social and Behavioral Sciences 2: 2771-2776.

37. Mishna F, Khoury-Kassabri M, Gadalla T, Daciuk J (2012) Risk factors for involvement in cyber bullying: Victims, bullies and bully-victims. Children and Youth Services Review 34: 63-70.
38. Slonje R, Smith PK (2008) Cyberbullying: Another main type of bullying? Scand J Psychol 49: 147-154.

39. Sengupta A, Chaudhuri A (2011) Are social networking sites a source of online harassment for teens? Evidence from survey data. Children and Youth Services Review 33: 284-290.

40. Raskauskas J, Stoltz AD (2007) Involvement in traditional and electronic bullying among adolescents. Developmental Psychology 43: 564-575.

41. Kowalski RM, Fedina C (2011) Cyber bullying in ADHD and asperger syndrome populations. Research in Autism Spectrum Disorders 5: 12011208.

42. Kowalski RM, Limber SP (2013) Psychological, physical, and academic correlates of cyberbullying and traditional bullying. J Adolesc Health 53: 13-20.

43. Machmutow K, Perren S, Sticca F, Alsaker FD (2012) Peer victimisation and depressive symptoms: Can specific coping strategies buffer the negative impact of cybervictimisation? Emotional and Behavioral Difficulties 17: 403-420.

44. Schneider SK, O’Donnell L, Stueve A, Coulter RWS (2012) Cyberbullying, school bullying, and psychological distress: A regional census of high school students. Am J Public Health 102: 171-177.

45. Ybarra ML (2004) Linkages between depressive symptomatology and internet harassment among young regular internet users. Cyberpsychol Behav 7: 247-257.

46. Sahin M (2012) The relationship between the cyberbullying/cybervictimization and loneliness among adolescents. Children and Youth Services Review 34: 834-837.

47. Šleglova V, Cerna A (2011) Cyberbullying in adolescent victims: Perception and coping. Cyberpsychology. Journal of Psychosocial Research on Cyberspace 5.

48. Mitchell KJ, Ybarra M, Finkelhor D (2007) The relative importance of online victimization in understanding depression, delinquency, and substance use. Child Maltreat 12: 314-324.

49. Blais J (2008) Chatting, befriending, and bullying: Adolescents' interne experiences and associated psychosocial outcomes (Unpublished doctoral dissertation). Queen's University, Kingston, Ontario.

50. Lazarus RS, Folkmann S (1984) Stress, appraisal and doping. Springer, New York, USA.

51. Parris L, Varjas K, Meyers J, Cutts H (2011) High School Student's Perceptions of Coping With Cyberbullying. Youth \& Society 20: 1-23.

52. Price M, Dalgleish J (2010) Cyberbullying: Experiences, impacts and coping strategies as described by Australian young people. Youth Studies Australia 29: 51-59.

53. Dehue F, Bolman C, Vollink T (2008) Cyberbullying: Youngster's Experiences and Parental Perception. Cyberpsychol Behav 11: 217-332.

54. Ding L, Velicer W, Harlow L (1995) Effect of estimation methods, number of indicators per factor and improper solutions on structural equation modeling fit indices. Structural Equation Modeling 2: 119-143.

55. Tanaka J (1987) How big is enough? Sample size and goodness-of-fit in structural equation models with latent variables. Child Development 58: $134-146$.

56. Marsh HW, Balla JR, McDonald, RP (1988) Goodness-of-Fit Indexes in Confirmatory Factor Analysis: The Effect of Sample Size. Psychological Bulletin 103: 391-410.

57. Tabachnick BG, Fidell LS (2007) Using multivariate statistics ( $5^{\text {th }}$ edn). Pearson, New York, USA. 
58. Li SM, Hsieh SC (2009) Validation of the Life Satisfaction Scale in College Students. Chang Gung Nursing 20: 192-198.

59. Chang C (1987) Study on university entrance examination stress syndrome. Journal of National Public Health Association Republic of China 6: 43-53.

60. Goldberger DP (1978) Manual of the general health questionnaire. NFER Publishing, England.

61. Li Q (2007) Bullying in the new playground: Research into cyberbullying and cyber victimisation. Australasian Journal of Educational Technology 23: 435-454.

62. Noret N, Rivers I (2006) The prevalence of bullying by text message or email: Result of a four year study. Poster Presented at British Psychological Society Annual Conference, Cardifft.

63. Yang DJ, Chiu JZ, Chen YK (2011) Examining the social influence on college students for playing online game: Gender differences and implications. Turkish Online Journal of Educational Technology 10: 115-122.
64. Ybarra ML, Mitchell KJ (2004) Youth engaging in online harassment: Associations with caregiver-child relationships, Internet use, and personal characteristics. J Adolesc 27: 319-336.

65. Khoury-Kassabri M (2009) The relationship between staff maltreatment of students and students' violent behavior. Child Abuse \& Neglect 33: 914923.

66. Barnett J, Coulson M (2010) Virtually real: A psychological perspective on massively multiplayer online games. Review of General Psychology 14: 167-179.

67. Brown HD (1994) Teaching by Principles: An Interactive Approach to Language Pedagogy. Prentice Hall Regents, New Jersey, USA. 


\section{If}

Advances In Industrial Biotechnology | ISSN: 2639-5665

Advances In Microbiology Research | ISSN: 2689-694X

Archives Of Surgery And Surgical Education | ISSN: 2689-3126

Archives Of Urology

Archives Of Zoological Studies | ISSN: 2640-7779

Current Trends Medical And Biological Engineering

International Journal Of Case Reports And Therapeutic Studies | ISSN: 2689-310X

Journal Of Addiction \& Addictive Disorders | ISSN: 2578-7276

Journal Of Agronomy \& Agricultural Science | ISSN: 2689-8292

Journal Of AIDS Clinical Research \& STDs | ISSN: 2572-7370

Journal Of Alcoholism Drug Abuse \& Substance Dependence | ISSN: 2572-9594

Journal Of Allergy Disorders \& Therapy | ISSN: 2470-749X

Journal Of Alternative Complementary \& Integrative Medicine | ISSN: 2470-7562

Journal Of Alzheimers \& Neurodegenerative Diseases | ISSN: 2572-9608

Journal Of Anesthesia \& Clinical Care | ISSN: 2378-8879

Journal Of Angiology \& Vascular Surgery | ISSN: 2572-7397

Journal Of Animal Research \& Veterinary Science | ISSN: 2639-3751

Journal Of Aquaculture \& Fisheries | ISSN: 2576-5523

Journal Of Atmospheric \& Earth Sciences | ISSN: 2689-8780

Journal Of Biotech Research \& Biochemistry

Journal Of Brain \& Neuroscience Research

Journal Of Cancer Biology \& Treatment | ISSN: 2470-7546

Journal Of Cardiology Study \& Research | ISSN: 2640-768X

Journal Of Cell Biology \& Cell Metabolism | ISSN: 2381-1943

Journal Of Clinical Dermatology \& Therapy | ISSN: 2378-8771

Journal Of Clinical Immunology \& Immunotherapy | ISSN: 2378-8844

Journal Of Clinical Studies \& Medical Case Reports | ISSN: 2378-8801

Journal Of Community Medicine \& Public Health Care | ISSN: 2381-1978

Journal Of Cytology \& Tissue Biology | ISSN: 2378-9107

Journal Of Dairy Research \& Technology | ISSN: 2688-9315

Journal Of Dentistry Oral Health \& Cosmesis | ISSN: 2473-6783

Journal Of Diabetes \& Metabolic Disorders | ISSN: 2381-201X

Journal Of Emergency Medicine Trauma \& Surgical Care | ISSN: 2378-8798

Journal Of Environmental Science Current Research | ISSN: 2643-5020

Journal Of Food Science \& Nutrition | ISSN: 2470-1076

Journal Of Forensic Legal \& Investigative Sciences | ISSN: 2473-733X

Journal Of Gastroenterology \& Hepatology Research | ISSN: 2574-2566
Journal Of Genetics \& Genomic Sciences | ISSN: 2574-2485

Journal Of Gerontology \& Geriatric Medicine | ISSN: 2381-8662

Journal Of Hematology Blood Transfusion \& Disorders | ISSN: 2572-2999

Journal Of Hospice \& Palliative Medical Care

Journal Of Human Endocrinology | ISSN: 2572-9640

Journal Of Infectious \& Non Infectious Diseases | ISSN: 2381-8654

Journal Of Internal Medicine \& Primary Healthcare | ISSN: 2574-2493

Journal Of Light \& Laser Current Trends

Journal Of Medicine Study \& Research | ISSN: 2639-5657

Journal Of Modern Chemical Sciences

Journal Of Nanotechnology Nanomedicine \& Nanobiotechnology | ISSN: 2381-2044

Journal Of Neonatology \& Clinical Pediatrics | ISSN: 2378-878X

Journal Of Nephrology \& Renal Therapy | ISSN: 2473-7313

Journal Of Non Invasive Vascular Investigation | ISSN: 2572-7400

Journal Of Nuclear Medicine Radiology \& Radiation Therapy | ISSN: 2572-7419

Journal Of Obesity \& Weight Loss | ISSN: 2473-7372

Journal Of Ophthalmology \& Clinical Research | ISSN: 2378-8887

Journal Of Orthopedic Research \& Physiotherapy | ISSN: 2381-2052

Journal Of Otolaryngology Head \& Neck Surgery | ISSN: 2573-010X

Journal Of Pathology Clinical \& Medical Research

Journal Of Pharmacology Pharmaceutics \& Pharmacovigilance | ISSN: 2639-5649

Journal Of Physical Medicine Rehabilitation \& Disabilities | ISSN: 2381-8670

Journal Of Plant Science Current Research | ISSN: 2639-3743

Journal Of Practical \& Professional Nursing | ISSN: 2639-5681

Journal Of Protein Research \& Bioinformatics

Journal Of Psychiatry Depression \& Anxiety | ISSN: 2573-0150

Journal Of Pulmonary Medicine \& Respiratory Research | ISSN: 2573-0177

Journal Of Reproductive Medicine Gynaecology \& Obstetrics | ISSN: 2574-2574

Journal Of Stem Cells Research Development \& Therapy | ISSN: 2381-2060

Journal Of Surgery Current Trends \& Innovations | ISSN: 2578-7284

Journal Of Toxicology Current Research | ISSN: 2639-3735

Journal Of Translational Science And Research

Journal Of Vaccines Research \& Vaccination | ISSN: 2573-0193

Journal Of Virology \& Antivirals

Sports Medicine And Injury Care Journal | ISSN: 2689-8829

Trends In Anatomy \& Physiology | ISSN: 2640-7752

Submit Your Manuscript: https://www.heraldopenaccess.us/submit-manuscript 